\title{
Forhandlinger af mangfoldighed i danske kommunernes kostpolitikker for dagtilbud
}

\author{
Warrer, Sarah Damgaard, cand.pæd. og PhD-studerende, Aarhus Universitet. E-mail: sach@edu.au.dk \\ Leer, Jonatan, PhD (mag.art) og adjunct, Aarhus Universitet. E-mail: jonle@edu.au.dk
}

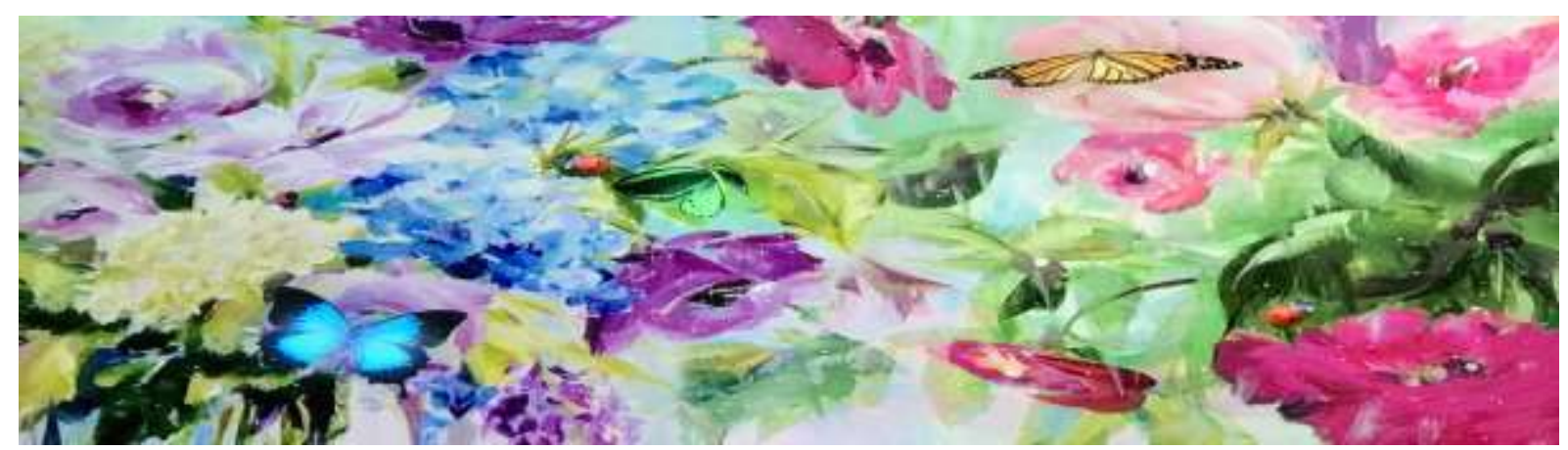

Sammendrag: Artiklen præsenterer en diskursanalytisk unders $\varnothing$ gelse af danske kommuners kostpolitikker. Formålet med studiet er at kortlægge kommunernes forhandling af mangfoldighed og den måltidspædagogiske opgave, hvilket udgør et arbejdsredskab for pædagogerne i kommunale dagtilbud. Studiet er baseret på en Laclau og Mouffe (1985) diskurs analyse. Studiet viser, at der ikke findes en entydig fælles forståelse af mangfoldighed og den måltidspædagogiske opgave i danske kommuner. Kommunernes forskellige tilgange og forhandlinger af den måltidspædagogiske opgave optræder i et kontinuum mellem en nationalkonservativ yderpol og en kosmopolitisk yderpol.

Nøgleord: småbørnspædagogik, kostpolitik, måltid, mangfoldighed

Abstract: The article presents a discourse analytical exploration of Danish Municipal meal guidelines. The purpose of the study is to map the municipalities' negotiation of diversity and the pedagogical meal assignments, which constitutes a tool for practitioners in municipal preschools. The study is based on a Laclau and Mouffe (1985) discourse analysis. The study indicates that there is no clear common understanding of diversity and the pedagogical meal assignment in Danish municipalities. The Municipalities' different approaches and negotiations of the pedagogical meal assignment appears in a continuum between a national conservative pole and a cosmopolitan pole.

Keywords: Early childhood education and care, policy, Meal, diversity 


\section{Indledning}

Dette studie kortlægger forhandlingen af mangfoldighed i danske kommuners kostpolitikker for dagtilbud.

Baggrunden er, at der i takt med øget diversitet i børnenes baggrund er kommet et $\varnothing$ get fokus på måltidets rolle i dagtilbud i en europæisk kontekst, ikke mindst fra politisk side (Vandsø, 2016). Til trods for en stigende pluralisme og normændring i den vestlige madkultur, hvor den enkelte forbruger er villig til at prøve nyt og selv finde frem til markører for, hvad der forstås som traditioner, sundhed, $\varnothing$ konomi, gastronomi og etik (Beardsworth \& Keil, 1997; Fischler, 1980; Holm, 2003; Ritzer, 2012), er et centralt tema i politiske debatter forholdet mellem videreførelsen af nationale madtraditioner over for hensyntagen til alternative normer og regler i forhold til måltider. I særdeleshed er svinekød og muslimer et eksempel, der ofte problematiseres i lande, hvor svinekød traditionelt har spillet en stor rolle i den nationale madkultur (Birnbaum, 2013).

Et eksempel på debatter om svinekød i regi af danske dagtilbud er den såkaldte "frikadellegate". Den udspillede sig i den danske by Randers, hvor byrådet i 2016 vedtog et forslag, der skulle sikre opretholdelsen af den danske madkultur. Forslaget var en reaktion på, at mange dagtilbud undlod svinekød eller erstattede det med alternative former for kød, således at alle kunne spise det samme (Hunter, 2016). Det førte til stor debat mellem dem, der mente, at den nationale madkultur (herunder svinekød) skulle spille en central rolle i dagtilbudsmåltiderne, og dem, der så det som en central opgave at sørge for, at alle kunne spise det samme uanset baggrund. Senest er debatten nu på folketings niveau, hvor Socialdemokratiet, Venstre og Dansk Folkeparti understreger, at de danske værdier og den danske kultur er for vigtigt et emne at overlade til de enkelte institutioner at bestemme og varetage, og bør derimod være under kommunalpolitisk styring (Danmarks Radio 2018). Den måltidspædagogiske opgave er et varmt politisk emne, men der synes således at mangle viden om, hvordan mangfoldighed forhandles mere generelt i de danske kommuner. Det er denne kortlægning, som denne artikel vil præsentere og diskutere.

\section{Dette studie фnsker at bidrage med en kortlagning af, hvordan mangfoldighed forhandles $i$ danske kommunale kostpolitikker.}

\section{Kommunale kostpolitikker og mangfoldighed}

Vi definerer mangfoldighed som en anerkendelse af, at alle mennesker er forskellige, det gælder også i forhold til religion, etniske oprindelse, holdninger og smagspræferencer (Dahlberg et al., 2013). I lyset af denne forståelse er dagtilbuddet en social mødeplads, hvor børn, forældre og pædagogiske personaler møder i dagtilbuddets sociale fællesskab med forskellige udgangspunkter.

På et globalt niveau, har der de sidste to årtier været et stærkt fokus på policymaking, og ifølge OECD er det demografiske landkort under udvikling, blandt andet er europæiske samfund blevet mere etniske-, kulturelle- og sprogligt mangfoldige, hvilket er med til at $\emptyset$ ge behovet for dagtilbudspolicy og en eksplicitering af, hvad der tilbydes (OECD, 2017). Dette afspejles også i De Forenede Nationers bæredygtige udviklingsmål 2015-2030 (SDG), hvor målet er, at børn blandt andet erhverver sig viden og færdigheder, så de kan bidrage til en bæredygtig udvikling, herunder inklusion,

menneskerettigheder, kulturel diversitet og global medborgerskab (United Nations, 2015). På nationalt lovgivningsniveau er dagtilbuddene forpligtet på, at give børn medbestemmelse, medansvar og forståelse for demokrati, og dette skal ske ved at børnene udvikler selvstændighed, evner til at indgå i 
forpligtende fællesskaber og oplever integration i det danske samfund (Børne- og Socialministeriet, 2015).

I Danmark får børn, der går i dagtilbud, dækket op til 70 \% af deres daglige madbehov i dagtilbuddet (Kristansen \& Andersen, 2015, p. 6; Nordic Council of Ministers, 2004). Måltidet og spisesituationen indgår derfor som en daglig pædagogisk aktivitet, hvor børn og voksne er samlet om at spise. Måltidet er derfor en oplagt arena for inklusion i dagtilbud, men også en situation, hvor forskelle i baggrund tydeliggøres (Jensen, 2012a). Børn og praktikere mødes om det fælles måltid i dagtilbuddet med individuelle normer, forståelser og vurderinger af fødevareres rangorden, og hvad 'rigtig' og 'god' mad er, det vil sige, hvad der er kulturelt og socialt passende at servere (Halkier, 2012; Jensen, 2012a). Praktikerne har ansvaret for at løfte måltidet ind i en pædagogisk kontekst med en måltidspædagogisk opgave, og spiller ligesom børnenes familie en vigtig rolle for børnenes måltidssocialisering (Bae, 2009). Ifølge Karrebæk $(2012,2013)$ vedrører madsocialiseringen dog mere end blot de ernæringsmæssige værdier. Traditionelle nationale madvarer så som rugbrød tillægges en højere sundhedsværdi end den mad børn fra minoritetsgrupper medbringer i deres madkasse. Måltidet i dagtilbuddet kan rumme tværkulturelle møder, og derfor er det også vigtigt, at praktikerne er bevidste om den måltidspædagogiske opgave og deres egen rolle heri.

Siden starten af 2000'erne har der forskningsmæssigt været interesse for politikker for mad og måltider i danske dagtilbud. Mens der i tidligere forskning er et stærkt fokus på indholdsmæssige temaer, synes de bagvedliggende diskurser at være et forsømt område (Andersen et al., 2004; COWI, 2007; Iversen, 2013; Iversen \& Sabinsky, 2011; Lissau et al., 2006; Møller Christensen \& Hjorth Frandsen, 2010).

Nogle undersøgelser afdækker om kostpolitikkerne opstiller mål, der følger Fødevarestyrelsens ernæringsmæssige anbefalinger, samt hvordan de forholder sig til sociale rammer, herunder normer, bordskik og tidsforbrug (COWI, 2007; J.D Iversen \& Sabinsky, 2011; Lissau et al., 2006; Møller Christensen \& Hjorth Frandsen, 2010). Endvidere sættes fokus på mål for børns deltagelse og medinddragelse i beslutningsprocesser og praktiske gøremål i forbindelse med måltider. Endnu en del af undersøgelserne afdækker også antallet af kostpolitikker, der adresserer tematiske elementer, som er blevet udtrykt i den offentlige debat, som for eksempel 'Slik og søde sager' (Andersen et al., 2004; Lissau et al., 2006). Det samme gør sig gældende for temaet 'økologi' (Andersen et al., 2004; COWI, 2007; Møller Christensen \& Hjorth Frandsen, 2010). Etniske minoriteter udgør et særskilt tema eller sammensat med allergikere under 'særlige grupper', og omhandler registreringen af hvor mange kostpolitikker, der har særskilte mål og holdninger til udvisningen af hensyn (Andersen et al., 2004; COWI, 2007).

Tidligere forskning peger på etniske minoriteter som et særskilt tema dagtilbuddene må forholde sig til, men ingen studier har i særdeleshed dokumenteret de underliggende diskurser heri. Så på trods af det øgede fokus på mangfoldighed og kulturel diversitet ved vi ganske lidt om, hvordan det er artikuleret i kommunale kostpolitikker eller, hvordan det omsættes i hverdagslivet i danske dagtilbud. Formålet med dette studie er derfor at kortlægge, hvordan mangfoldighed forhandles i danske kommuners kostpolitikker for dagtilbud.

\section{Teoretisk forankring}

De kommunale kostpolitikker er formuleret og styret af lovgivning og politiske beslutninger med henblik på at sikre en særlig pædagogik og opdragelse. Til analysen adopteres to teoretiske tilgange. For det første adopteres Dahlberg et al. (2013) postmoderne perspektiv på dagtilbuddet, som et mødested med mangfoldige interesser og identiteter, hvor meningsskabelsen sker i relationen med 
andre. Det meningsfulde forhandles i fællesskabet og eksisterer kun i kraft af dette fællesskab. Det betyder, at hvad der opleves som meningsfyldt i måltidsfællesskabet på rød stue ikke nødvendigvis opleves som meningsfuldt på blå stue. Denne forståelse rummer en kritik af objektive universelle standarder som i forhold til mad og måltider kan vedrøre fælles forståelser af, hvad der karakteriserer 'den gode smag' og 'det rigtige måltid' og dermed 'den dårlige smag' og 'det forkerte måltid'. For det andet anvendes DeSoucey's (2010) begreb gastronationalisme, som ser måltidet som et rum til at skabe en national identitet midt i en global tidsalder.

Ifølge DeSoucey (2010) kan begrebet gastronationalisme forstås som madpraksisser, der bruges til at forme og promovere en bestemt fortælling om nationen. Gastronationalisme fungerer både på et supranationalt niveau, når mad bruges til at tegne grænser op mellem lande, men også på et subnationalt niveau (Wright \& Annes, 2013), hvor mad bruges internt i en nation til at definere rigtige og forkerte medborgere. Særligt i takt med globaliseringen og generel opløsning af traditionelle madkulturer forekommer gastronationalistiske diskurser i stigning (Leer, 2018). I dette studie anlægges det subnationale perspektiv på mangfoldighed i kommunernes retningslinjer for måltidet.

Måltidet kan forstås som et socialt mødested, hvor kommunens børn, forældre, pædagoger og politikere sammen deltager i og om et socialt, kulturelt og politisk projekt (Dahlberg et al., 2013). De kommunale kostpolitikker kan i denne optik anskues som kommunens bidrag til at rammesætte dette sociale projekt. Måltidet anskues som et socialt rum, 1) der deles mellem praktikerne og børn, og bidrager med unikke muligheder for at opleve at være en del af et fællesskab, der rummer mangfoldighed, kompleksitet og individualisme 2) der giver mulighed for at være forpligtet på ligeværdighed - en ligeværdighed, der anerkender den anden som forskellig, frem for en forståelse for ligeværdighed som ensartethed.

Måltidet kan i denne optik blive et socialt mødested, hvor viden og meningsskabelse er baseret på debat og dissensus, frem for at være et sted, hvor sandheden findes ved at overføre den etablerede viden og konsensus om enhed til børnene eller at påføre dem normaliseringsteknikker (Dahlberg et al., 2013). Anerkendelsen af pluralitet medfører en anden forståelse for børnene. Børnene er betydningsfulde og kompetente agenter i fællesskabet, der aktivt deltager i meningsskabelsen (Malaguzzi, 1993).

Dette perspektiv udfordrer forståelsen af måltidsfællesskabet som et lukket og stabilt fællesskab med sammenhængende interesser og identiteter, men derimod som mangfoldige interesser og identiteter. Uenighed og diskussioner er nødvendige aspekter i et fællesskab, og et udtryk for at demokratiet eksisterer og er beboet af pluralisme. Fællesskabet som en kollektiv identitet konstrueres netop gennem børnene og praktikernes kommunikation, forhandling og konfrontation. Dette er forudsætningen for at være i stand til at rejse spørgsmål om mening og udfordrer den accepterede viden og diskurser om 'den gode smag' og 'det rigtige måltid' (Dahlberg et al., 2013).

\section{Metode}

Studiets analyse af mangfoldighed i kommunale kostpolitikker er baseret på Laclau og Mouffes (1985) diskusanalytiske metode. I dette social konstruktivistiske perspektiv analyseres, hvordan forskellige italesættelser af verdenen ikke bare reflekterer virkelighed, men er med til at skabe virkeligheden. Analysen er derfor også en analyse af den virkelighed, disse politikker indgår i og er medskabere af; og herunder også en analyse af de ideologisk betingede værdisæt og strukturerende kræfter, der former denne sociale virkelighed.

Den diskursanalytiske tilgang til kommunernes politikker er karakteriseret ved at den fokuserer på to niveauer. På første niveau fokuseres på den enkelte kommunale kostpolitik og på, 
hvordan bestemte betydningskæder fikseres og normaliseres heri. Herved legitimerer den enkelte kostpolitik bestemte måltidsformer og måder at spise på, mens andre de-legitimeres. I forlængelse heraf legitimeres de subjekter, der lever op til de legitime praksisser, mens de, der ikke gør det, mistænkeliggøres. På andet niveau analyseres på tværs af korpusset af tekster, hvordan de forskellige tekster udgør forskellige bud på, hvad det gode måltid i dagtilbud er med særlig fokus på artikulationer af det nationale og det globale. Således anses det samlede korpus som indeholdende konkurrerende bud på eller forhandlinger af modsætningsforholdet mellem dansk madkultur og en åbenhed for minoriteter. Helheden af tekster anses som en kamp om at formulere den hegemoniske forståelse af dette forhold.

Empirien er indsamlet i perioden januar - april 2016. Den diskursive analyse af kommunernes politikker er udført i følgende separate faser, men dog som del af et sammenhængende hele;

Forst rekvireres politikker for mad og måltider via landets 98 kommuners hjemmesider. I tilfælde hvor det ikke var muligt at lokalisere politikker via kommunens hjemmeside, blev kommunerne kontaktet telefonisk. Der forefindes politikker hos 63 af de i alt 98 kommuner, svarende til 64,3\% af landet kommuner. Disse 63 politikker indgår i analysen (se vedhæftede bilag, Tabel 1). Det er ikke et krav, at der forefindes politikker på området, hvorfor det i nogle kommuner ligger lokalt hos dagtilbuddene at udarbejde en politik. Politikker på institutionsniveau indgår ikke i analysen.

Den anden fase omhandlede læsning og genlæsning politikkerne med henblik på at blive fortrolig med materialet og danne et overblik over det samlede materiale. I politikkerne optræder mangfoldighed som en særskilt tematisk kategori ligesom 'sukker og søde sager', 'økologi' og 'allergikere'. Alt tekst under denne særskilte tematiske kategori omhandlende mangfoldighed og børnegruppens sammensætning inddrages i analysen. Begge forskere læste politikkerne, og noterede overordnede kategorier af udsagn, der vedrører mangfoldighed og børnegruppens sammensætning.

Tredje fase omhandlede en systematisk undersøgelse af konstruktionen af diskurser i politikkerne som enkeltstående dokumenter foregik i plenum mellem de to forskere. Fremgangsmåden til behandling af empirien i denne fase er baseret på følgende metodiske spørgsmål: 1) Hvilke nodalpunkter og flydende betegnere er til stede? 2) Hvordan er diskurserne konstrueret og hvilke momenter knyttes til nodalpunkterne? 3) Hvilke elementer befinder sig i det konstitutive ydre? Hele sætninger og tekstbidder blev anvendt som en enhed i analysen. Sætninger og tekstbidder som nævner mangfoldighed eller er relateret hertil blev medtaget i analysen. Når sætninger og tekstbidder udvælges medtages en rimelig del af det omgivende tekst for at undgå at miste konteksten. Politikkerne spænder bredt i det tekstmæssige omfang, nogle kommuner er meget overordnet og i punktform, hvor andre har mere forklarende tekst. Dette afspejles også i de bragte citater.

Fjerde fase omhandlede en læsning og sortering af sætninger og tekstbidder. På baggrund af fase tre udarbejdes et kontinuum mellem to yderpoler i materialet (Figur 1). Den ene yderpol udgør en nationalkonservative position, hvori en central del af måltidet har til opgave at videreføre og konservere en dansk madkultur via måltidet. Her vægtes danskhed tungere end åbenhed over for andre kulturer og hensyntagen til særlige spiseregler. I politikkerne optræder svinekød som en forskelsmarkør, idet en række kommuner eksplicit omtaler forbud mod at spise svinekød. Den anden yderposition udgør en kosmopolitiske position, hvori måltidet har til opgave at bidrage til globalt udsyn og anerkendelse af hinandens forskellige mad- og smagspræferencer og madkulturer. I denne position forefindes ikke en hierarkisk skelnen mellem dansk og ikke-dansk mad. Vi placerede herefter teksterne i kontinuummet. Ud fra denne kortlægning definerede vi tre overordnede betragtemåder på mangfoldighed, som opstod på tværs af det samlede korpus; 1) en skelnen mellem 'os' og 'de fremmede', 2) en skelnen mellem 'os' og 'de andre' og 3) 'vi er alle forskellige'. Disse positioner er generet empirisk på baggrund af teksternes ordlyd. Inden for disse tre overordnede tilgange positionerede politikkerne sig yderligere i ni forskellige mellempositioner baseret på den måltidspædagogiske opgave i forbindelse med mangfoldighed (Figur 2). 


\section{Analyse og resultater}

På baggrund af materialet har vi altså valgt at kortlægge vores korpus i et mangfoldighedskontinuum, hvor den ene pol udgør en nationalkonservativ pol og den anden en kosmopolitisk pol. Disse poler er generet empirisk med øje for måden, hvorpå teksterne italesatte forholdet mellem dansk madkultur og børn, der ikke må spise svinekød. Kortlægningen udgør et kontinuum, fordi vi fandt en række mellempositioner. I den nationalkonservative pol lægges vægt på en videreførelse af en dansk madkultur og en forventning om anderledes spisendes underordning af dette. Hvor den kosmopolitiske pol lægger vægt på en global madtradition og en sidestilling af børnenes mad- og smagspræferencer og madkulturer. Således er det på ingen måde vores idé at dele kostpolitikkerne dikotomisk op i to grupper, men snarere at se teksterne som forskellige forhandlinger af forholdet mellem nationalisme og kosmopolitisme, der kan positioneres i forhold til hinanden (Figur 1).

Med udgangspunkt i en induktiv tilgang til empiriens ordvalg opstod tre overordnede betragtningsmåder på mangfoldighed; 1) en skelnen mellem 'os' og 'de fremmede', 2) en skelnen mellem 'os' og 'de andre' og 3) 'vi er alle forskellige'. I disse betragtemåder, fandt vi tre forskellige forestillinger om måltidets opdragende potentiale: 1) opdrage til danskhed 2) opdrage til respekt for andre 3) opdrage til mangfoldighed.

Figur 1 illustrerer kontinuummets overordnede betragtemåder for måltidets opdragende potentiale. Figur 2 illustrerer andelen af kommuner i kontinuummets positioner.

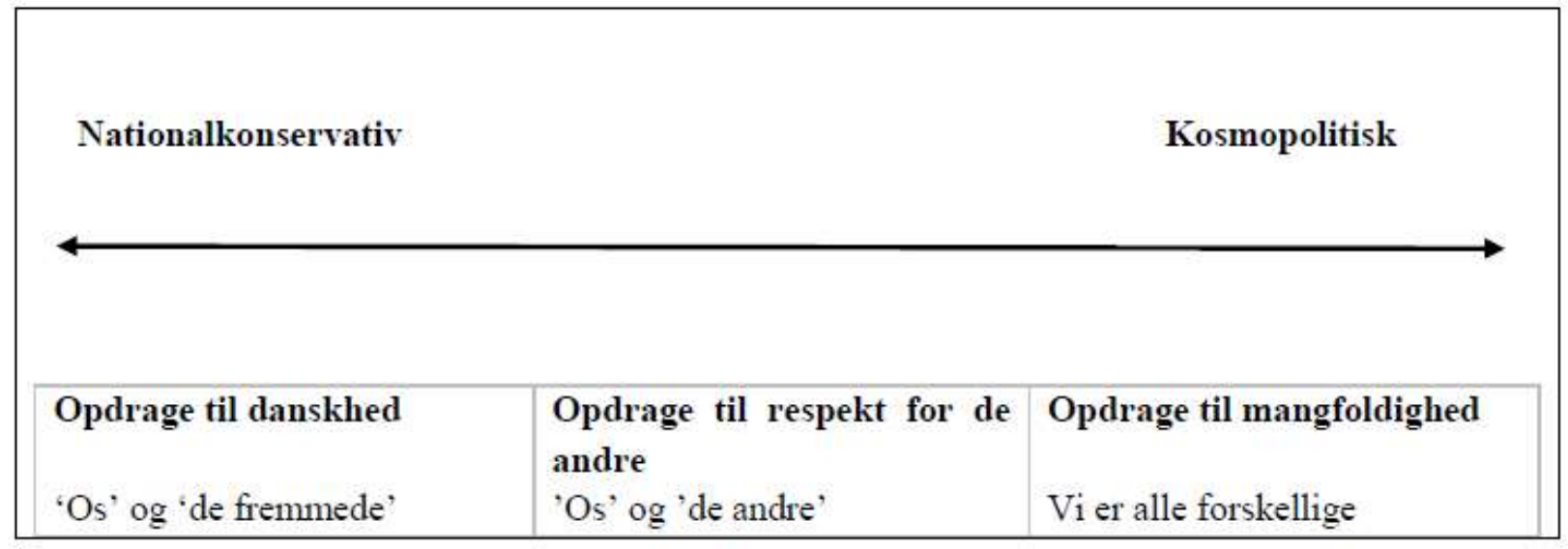

Figur 1: Mangfoldigheds kontinuum. 


\begin{tabular}{|c|c|c|}
\hline $\begin{array}{l}\text { Tilgange til } \\
\text { mangfoldighed }\end{array}$ & Positioner & $\begin{array}{l}\text { Kommuner som } \\
\text { har en kommunal } \\
\text { kost-politik med } \\
\text { denne tilgang til } \\
\text { mangfoldighed }^{1}\end{array}$ \\
\hline \multirow[t]{2}{*}{ Opdrage til danskhed } & $\begin{array}{l}\text { Dansk madkultur- og identitet truet af de } \\
\text { fremmede }\end{array}$ & $3 \%$ \\
\hline & $\begin{array}{l}\text { Dansk madkultur med begræenset hensyn til } \\
\text { andre kulturer }\end{array}$ & $13 \%$ \\
\hline \multirow[t]{4}{*}{$\begin{array}{l}\text { Opdrage til respekt for de } \\
\text { andre }\end{array}$} & $\begin{array}{l}\text { Majoriteten bestemmer lokalt omfanget af } \\
\text { hensyn til minoriteter }\end{array}$ & $8 \%$ \\
\hline & $\begin{array}{l}\text { Dansk madkultur åben for at hjzelpe de } \\
\text { andre ind }\end{array}$ & $3 \%$ \\
\hline & $\begin{array}{l}\text { Alle skal have sund mad - måltidet som } \\
\text { værktøj til gensidig forståelse }\end{array}$ & $11 \%$ \\
\hline & Ligestilling i retten til fravalg af fødevarer & $6 \%$ \\
\hline \multirow[t]{3}{*}{$\begin{array}{l}\text { Opdrage til } \\
\text { mangfoldighed }\end{array}$} & $\begin{array}{l}\text { Måltidet respekterer og afspejler } \\
\text { forskellighed }\end{array}$ & $8 \%$ \\
\hline & $\begin{array}{l}\text { Dynamisk madkultur og måltidet som } \\
\text { værktøj gensidig forståelse }\end{array}$ & $11 \%$ \\
\hline & Global madkultur, hvor alle er forskellige & $6 \%$ \\
\hline
\end{tabular}

Figur 2: Oversigt over ni positioner af tilgange til mangfoldighed.

I det følgende beskrives og analyseres disse 9 positioner. I analysen inddrages et udvalg af citater fra politikkerne. Nogle kommuner har identiske eller næsten enslydende beskrivelser, hvorfor vi har valgt ikke at citere dem alle.

\section{Dansk madkultur- og identitet truet af de fremmede}

Denne position synes to kommuner at have. I denne position anskues en dansk madkultur og kulturarv som en ufravigelig og entydig norm, hvor dagtilbuddets rolle og måltidets centrale opgave er at opdrage børn i denne kultur. Madkulturer fra andre lande italesættes som "fremmede" madkulturer, og lades samtidig med en betydning om at udgøre en trussel mod danskheden og dagtilbuddets opdragende rolle, hvorfor dagtilbuddets rolle er at stå fast over for denne trussel. Svinekød konstrueres og bruges som karakteristik af dansk madkultur. Endvidere insisteres på, at der skal serveres svinekød som markering af, at danskhed ikke skal føje sig efter fx muslimske mindretal. Hensynet til børns rettigheder og behov for et sundt måltid efter Fødevarestyrelsens (2015) Y-tallerken model, hvor 
$20 \%$ af måltidet bør udgøre en proteinkilde, er sekundært ved fravalg af svinekød. Dette kommer til udtryk i politikkerne således;

Madplanen reprasenterer en varieret dansk madkultur, hvor der indgår forskellige kødtyper heriblandt svinek $\phi d$ (Glostrup kommune, 2015).

Fremmed madkultur skal betragtes som supplement til - ikke erstatning for - dansk madkultur. Hensynet til fremmede kulturer må ikke hindre, at der serveres traditionelle danske retter (Hvidovre kommune, årstal ikke angivet).

\section{Dansk madkultur med begranset hensyn til andre kulturer}

Denne position synes otte kommuner at have. Maden skal ligesom i punkt 1 være "dansk", og måltid ses som en vej til at videreføre en særlig dansk identitet. Den adskiller sig fra punkt 1 ved, at de "fremmede" i mindre grad ses som en direkte trussel, idet der "vises respekt for" religiøse og kulturelle forskrifter. Respekten og hensynet er sekundært, idet den begrænses til, at der ikke tilbydes alternativer ved servering af svinekød:

Hvis der for eksempel serveres svinekфd med ris, sovs og grøntsager, skal et barn, der af religiфs overbevisning ikke spiser svinek $\phi$, have dakket sit energibehov ved at fä mere ris, sovs og grønt (Gladsaxe kommune, 2013).

Børn fra fremmede kulturer kan sagtens spise sig matte i almindelige kosttilbud (Allerød kommune, 2007).

Børn fra fremmede kulturer får tilbudt det samme mad som danske børn (Lemvig kommune, 2015).

Børn, der ikke spiser svinekød, tilbydes altså ikke en alternativ proteinkilde, således at Y-tallerkenen opretholdes. De religiøse forskrifter fratager altså barnet retten til et ernæringsrigtigt måltid.

\section{Majoriteten bestemmer lokalt omfanget af hensyn til minoriteter}

Denne position synes fem kommuner at have. I denne position flyttes fokus i den måltidspædagogiske opgave fra i mindre grad at være opretholdelsen af den danske madkultur til, at alle skal have et sundt og ernæringsrigtigt måltid. I denne position forekommer stadig en skelnen mellem 'dem' og 'os'. Hvor 'dem' dækker over religiøse minoriteter, der fravælger bestemte fødevarer, og 'os' udgør majoriteten, som besidder definitionsmagten. I denne position anses det ikke som en kommunal opgave at lave retningslinjer for omfanget af hensyn til minoriteter, hvorfor det lægges ud til lokal forhandling mellem dagtilbuddet og forældrebestyrelse. I denne position vægtes dialog og forhandling af den lokale madkultur højt, dog med den bemærkning at dette foregår hos majoriteten om minoriteten. De "andre" kulturer anskues ikke som en trussel, men snarere en ubelejlig minoritet, som majoriteten kan vælge at respektere:

Det er op til dagtilbuddet sammen med forceldrebestyrelsen at beslutte, hvordan der tages hensyn til behov, som udspringer af forskellig etnisk baggrund og andre forceldreønsker (Helsingør kommune, 2013).

Alle bestyrelser skal drøfte, i hvilket omfang der skal tilbydes sarlig mad til børn på dicet og til børn fra andre kulturer (Roskilde, 2008). 
Nedenstående spørgsmål kan vare inspiration til debat $i$ kostudvalget (...). Hvordan forholder vi os til mad til børn fra andre religioner/ kulturer? (Rødovre, 2009).

\section{Dansk madkultur åben for at hjoelpe de andre ind}

Denne position synes to kommuner at have. I denne position er den måltidspædagogiske opgave, at alle får et sundt måltid, og hvor gruppen af fremmede hjælpes ind i den sunde madkultur. En madkultur som den danske majoritet har nøglen til at forstå og definere. Der ekspliciteres ikke direkte en dansk madkultur, men det ligger implicit i udpegningen af en gruppe af fremmede, som har en anden madkultur end den danske majoritet. Der foregår også en skelnen mellem dem og os, hvor definitionsmagten ligger hos majoriteten. De fremmede ses ikke som en trussel, men en minoritet af 'eksotiske væsener', som majoriteten kan give plads til ved at prøve at spise deres mad. Dette udtrykkes for eksempel således:

Der prøves mad fra fremmed kulturer (Læsø kommune, årstal ikke angivet).

Dette kan både tolkes som en større grad af rummelighed, idet der opfordres til at servere retter fra andre dele af verden og derfor en åbning mod de andre. Samtidig er det med til at rammesætte dem som anderledes.

I Thisted kommune understreges forpligtelsen til at give flygtninge og indvandrer vejledning $\mathrm{i}$ sundhed, da de ofte har "en anden holdning til og viden om sund kost og kostsammensatning" og:

da en del flygtninge og indvandrere er analfabeter, kan der med fordel også anvendes utraditionelle metoder i formidlingen, eksempelvis via billeder, små enkle foldere, video eller spil, der illustrerer, hvad der er sundt samt betydningen heraf (Thisted kommune, 2009).

Dette omsorgsarbejde indikerer en forståelse af minoriteten som sundhedsmæssigt handicappede og bidrager til skabelsen af et hierarki mellem majoriteten og minoriteten. Det er i høj grad med til at sætte lighed mellem sundhed, dansk kost og danskere, mens der konstrueres en akvivalænskæde mellem tilflyttere, ikke-dansk kost, uvidenhed og usundhed.

\section{Alle skal have sund mad-måltidet som vaerktøj til gensidig forståelse}

Denne position synes syv kommuner at have. Den madpædagogiske opgave synes her at sikre, at alle får et ernæringsrigtigt måltidet, hvor måltidet tildeles en vigtig funktion $\mathrm{i}$ arbejdet med gensidig forståelse. Dog forekommer en skelnen mellem majoriteten og minoriteten, idet der forekommer en udpegning af andre fra fremmede kulturer og det danske. Udvekslingen af gensidig forståelse må ske mellem majoriteten og minoriteten. Dette kommer bl.a. til udtryk således:

Børn, der af religiфse grunde har sarlige krav til maden, kan også rummes inden for frokostordningen. Kфkkenet er $i$ stand til at imødekomme dit barns behov for fx ikke at spise svinek $\phi$, og garanterer at der alligevel kan serveres et fyldestgфrende måltid (Egedal, 2015).

ALLE børn skal have et sundt frokostmåltid i dagtilbuddet - derfor skal der udvises sarligt hensyn til børn med allergi o.l. Endvidere skal der $i$ videst muligt omfang tages hensyn til religiøse og ideologiske forhold/holdninger (Guldborgssund, årstal ikke angivet).

Mad fra fremmede kulturer kan vare et padagogisk varkt $\emptyset$, der fremmer den gensidige forstålse i institutionen (Morsø kommune, 2003). 
Den mad, der tilbydes børn og unge, skal give alle lige mulighed for at spise sig matte $i$ et sundt ernaringsrigtigt måltid. Omkring måltidet mødes forskellige kostvaner og traditioner. Det er vigtigt at produkter valges ud fra miljøbevidsthed og varernes friskhed. Måltidet kan bruges som et padagogisk varktøj til at fremme en gensidig forståelse (Mariagerfjord, årstal ikke angivet).

Minoriteten af "fremmede" mennesker og madvaner italesættes ikke som en trussel, men som en pædagogisk mulighed for at arbejde med gensidig forståelse.

\section{Ligestilling $i$ retten til fravalg af fødevarer}

Denne position synes fire kommuner at have. I denne position er den pædagogiske opgave også, at alle skal have et sundt måltid, hvor religiøse og kulturelle forbehold samt allergi og helbredsmæssige begrundelser for fravalg af bestemte fødevare tildeles samme legitimitet og hensyn. Denne position har en praktisk ordlyd i forhold til at præcisere barnets rettigheder, men ekspliciterer ikke et pædagogisk sigte i måltidets mulighed for at arbejde med mangfoldighed.

Der tages hensyn til børn på dicet og børn fra andre kulturer (dicetkost er laggeordineret) (Hørsholm, årstal ikke angivet).

Tage hensyn til kulturel og religiфs mangfoldighed og børn med sarlige behov (Bornholm kommune, 2014).

Der skal tages rimelige hensyn til kultur, religion og specielle kroniske lidelser (Slagelse, 2013).

\section{Måltidet respekterer og afspejler forskellighed}

Denne position synes fem kommuner at have. I denne position er den pædagogiske opgave, at alle skal have et sundt måltid, og at måltidet afspejler mangfoldighed. Der forekommer ikke en skelnen mellem majoritet og minoritet, idet der her tales om forskellige kulturers kostvaner. Det indikerer en større grad af relativisme og mangfoldighed, der forpligtiger dagtilbuddene på at rumme forskelligheder og en flerhed af kulturer. Det udtrykkes bl.a. således:

Omkring måltidet mødes forskellige kostvaner og traditioner. I en børnegruppe vil der ofte vare børn, der af religiфse eller kulturelle årsager har sarlige regler eller forbehold til mad. I det omfang institutionen eller skolen serverer mad, skal alle børn uanset kulturel baggrund have mulighed for at spise sig matte $i$ et sundt og ernaringsrigtigt sammensat måltid (Halsnæs kommune, 2009).

Børn, der af kulturelle eller religiøse årsager fravalger bestemte fødeemner skal sikres et ernaringsrigtigt alternativ. Foraldrene og dagpleje/daginstitution/skole/SFO har $i$ samarbejde ansvaret for at dette sker (Brøndby, 2003).

Der vises respekt for forskellige kulturers kostvaner. Den mad, der tilbydes i dagtilbuddene, skal give alle børn lige mulighed for at spise sig matte i et sundt, ernaringsrigtigt måltid (Furesø, 2010). 
8. Dynamisk madkultur og måltidet som varktøj gensidig forståelse

Denne position synes syv kommuner at have. I denne position er den pædagogiske opgave, at alle skal have et sundt måltid, hvor måltidet anskues som et mangfoldigt mødested, der fremmer gensidig forståelse. Det kommer bl.a. til udtryk således:

Den mad, der tilbydes i dagtilbud, skole og døgninstitution, skal give alle børn og unge uanset kulturel og religiøs baggrund mulighed for at spise sig matte i et sundt og ernaringsrigtigt måltid. Måltidet kan udgфre rammerne for mødet mellem forskellige kostvaner og traditioner, og måltidet kan derfor anskues som en padagogisk aktivitet til at fremme gensidig forståelse og respekt blandt børn og unge (Aabenraa kommune, 2010).

Alle børn uanset kulturel baggrund skal have mulighed for at spise sig matte i et ernaringsrigtigt måltid. Omkring måltidet mødes forskellige traditioner og kostvaner, og der skal udvises respekt for dette (Nyborg, 2015).

Dagtilbuddene forpligtes på at fremstille mad, der afspejle mangfoldighed. Dette kommer til udtryk i en forståelse af madkultur som noget dynamisk, der forandres med børnegruppens sammensætning.

Den mad, der tilbydes i dagtilbud skal tage udgangspunkt $i$ den danske madtradition, som løbende påvirkes fra forskellig side. Det er vigtigt, at måltidet foregår i et inkluderende fallesskab. Der skal vises respekt for de madkulturer børnene kender hjemmefra (Høje Taastrup, 2011).

9. Global madkultur, hvor alle er forskellige

Denne position synes fire kommuner at have. I denne position er den måltidspædagogiske opgave, at alle har mulighed for at spise sig mætte i et sundt måltid, der sikres gennem en global madkultur med et bredt sortiment af retter:

Der arbejdes for et bredt udvalg af retter, således at den enkelte kan valge mad efter egne behov, praferencer, normer og kultur (Faxe kommune, 2010).

Forskellighed italesættes som et generelt fænomen, der betoner vigtigheden i, at alle børn og hjem er forskellige, hvormed opdelingen i os og dem forsvinder. Måltidet anskues som et globalt mødested, hvor madkulturen forhandles og afspejler børnegruppens sammensætning:

Den mad, der tilbydes, tager udgangspunkt i en global kulturtradition (Middelfart kommune, årstal ikke angivet).

Maden planlagges ud fra børnegruppens sammensatning. Den mad, der tilbydes $i$ dagtilbuddene skal give alle børn - uanset kulturel baggrund - lige muligheder for at spise sig matte i et sundt ernaringsrigtigt måltid. Forceldre kan efter religiфs overbevisning fravalge bestemte fødevarer for deres børn (Lolland kommune, 2008).

Endvidere adresseres de voksnes normativitet som en mulig barriere for realiseringen af idealet om mangfoldighed. 
Det er vigtigt, at de voksne er bevidste om egen måltidskultur og samtidig respekterer forskelligheder i børnenes og dermed hjemmenes måltidskulturer (Struer, 2001).

\section{Diskussion}

Formålet med studiet var at kortlægge kommunernes forhandling af mangfoldighed i deres kostpolitikker. I dette afsnit diskuteres kortlægningen af kostpolitikkernes diskurser. Vi vil fokusere på fire elementer, som vi fandt særligt bemærkelsesværdige ved kortlægningen i lyset af de postmodernistiske og gastronationalistiske teorier, som har været vores teoretiske rammesætning. Endelig reflekteres diskurserne ud fra et diskursteoretisk perspektiv med reference til Mouffe og Laclau (1985) såvel som metodens begrænsninger.

\section{Dansk mad og det danske faellesskab}

Det er bemærkelsesværdigt, at nogle kommuner refererer til en dansk madkulturtradition. Denne madtradition defineres ikke eksplicit, men synes i højere grad at blive defineret negativt i forhold til det, der betegnes som fremmed madkultur.

Den danske madkultur fremstår som et fælles køkken for alle danskere på tværs af geografi og socioøkonomiske vilkår. Dette på trods af, at madforskning siden Bourdieus La Distinction (1979) har insisteret på, at måltidet ikke nødvendigvis samler store befolkningsgrupper med forskelligt sociale uddannelsesniveau og økonomi. Tværtimod er måltidet i høj grad et sted, hvor sociale forskelle blev markante og måske endda forstærket (Jensen, 2012b; Stamer, 2016). Dermed er mad ikke kun et samlingspunkt, men altså også et rum for markering af sociale skel og forskelligheder i livsstil (Jensen, 2012a; Kristensen \& Rasmussen, 2012; Smidt, 2012).

Den fremmede madkultur defineres heller ikke eksplicit, men fremstår som dem, der ikke spiser svinekød. Når det netop er grisen, der kommer til at udgøre symbol på danskhed og skillelinjen mellem danske og ikke-danske børn, så tenderer det til, at de fremmede i højere grad kobles til muslimer (Wright \& Annes, 2013).

\section{Sundhed og danskhed}

I et gastronationalistisk perspektiv er en del af diskursen om dansk madtradition ligeledes, at forme og promovere en særlig fortælling om den danske nation og den danske madkultur, som associeres med sundhed. Den danske madkultur adskiller sig derfor også fra den fremmede mad, som kobles til usundhed. I forlængelse heraf anses de, der spiser fremmed mad som mindre sunde. Fx i Thisted kommune, hvor det betones at flygtninge og indvandrer har"en anden holdning til og viden om sund kost og kostsammensatning", og der er behov for at guide dem mod en mere sund dansk madkultur.

Det er tankevækkende, at flere kostpolitikker anser den danske madtradition med svinekød som særlig sund. Den gennemsnitlige danske kost er derimod blevet problematiseret af flere studier, ikke mindst Meyer et al (2010) og Mithril et al (2012). Når kostpolitikkerne alligevel med største selvfølgelighed laver denne slutning mellem ernæringsrigtig mad og dansk mad, så kobles den umiddelbart objektive, videnskabelige sundhedsdiskurs til den ideologiske forestilling om den danske madkulturs overlegenhed.

\section{Mangfoldighed som vardi fra postmoderne perspektiv}

I nogle af kommunernes politikker synes den måltidspædagogiske opgave at vedrøre en opdragelse i en dansk madtradition, hvilket kan indikere, at denne tradition og den dertilhørende danske identitet er i fare. For megen hensyntagen til de fremmede risikerer at bringe den danske madkultur og den danske 
identitet i fare. Måltidet gøres dermed til et værn mod en udefrakommende trussel på den nationale identitet (DeSoucey 2010, Leer 2018, Wright \& Anne, 2013).

I lyset af Danmarks ratificering af FNs konvention for børns rettigheder i 1991 er det problematisk, at nogle kommuners kostpolitik synes at have et nationalkonservativt blik for den måltidspædagogiske opgave, som skaber et $o s$ og dem, der forventes praktiseret i mødet mellem praktikere, børn og forældre i dagtilbuddene. Nogle kostpolitikker problematiserer, at alle børn uden undtagelse har ret til at blive beskyttet mod alle former for diskrimination, forskelsbehandling eller straf på baggrund af barnet og dets forældres religion og etniske oprindelse m.v. (Udenrigsministeriet, 1992). Når nogle kommuner retningssætter, at måltidet i dagtilbuddet er baseret på danske retter herunder indeholdende svinekød, og at der ikke tilbydes et passende alternativ til de børn, der ikke spiser svinekød, hvorfor de derfor må spise sig mætte i tilbehør, må det ikke alene anses som et problem i forhold til konventionen, da det er forskelsbehandling på baggrund af barnets religion. Det strider også imod Fødevarestyrelsens anbefalinger om at spise efter Y-tallerkenen, hvor $20 \%$ af måltidet bør indeholde en proteinkilde (Haukrogh \& Køngerskov, 2009, p. 36).

I forståelsen af dagtilbuddet som et mødested for mangfoldige interesser er det vigtigt, hvilken position det enkelte barn tilskrives i måltidsfællesskabet (Dahlberg et al., 2013). Når fokus rettes mod danskhed som norm i måltidsfællesskabet, er der en fare for at de børn, der ikke lever op til denne norm, sættes i en marginaliseret udsat position. Derimod når alle børns stemmer involveres $\mathrm{i}$ beslutninger og meningsskabelse, og de til fulde oplever muligheden for at deltage $\mathrm{i}$ måltidsfællesskabet, kan det være en måde at opfylde børns rettigheder og anerkende deres potentialer som medborgere (Hart, 2008).

\section{Manglende konsensus mellem danske kommuners håndtering af mangfoldighed}

Et påfaldende fund i kortlægningen af kommunernes kostpolitikker er den manglende konsensus om håndteringen af mangfoldighed. Herunder er det slående, hvor få kommuner, der forholder sig eksplicit til mangfoldighed. Kun 44 af de 63 kostpolitikker svarende til 69,8\% forholder sig eksplicit til mangfoldighed. Til de 19 kostpolitikker som ikke forholder sig eksplicit til mangfoldighed, skal der tilføjes, at 35 kommuner ikke har en kommunal kostpolitik, og ansvaret for beslutninger om mangfoldighed er lagt ud til dagtilbuddene lokalt. Det betyder, at over halvdelen af Danmarks kommuner (55\%) ikke har en entydig politisk retning, der garanterer, hvordan mangfoldighed håndteres i løsningen af den måltidspædagogiske opgave og opdragelse i kommunernes dagtilbud.

Hertil kommer, at blandt de kommuner, der forholder sig til mangfoldighed, er der meget stor forskel. Kortlægningen viser, at der på kommunal politisk niveau er store forskelle i, hvordan mangfoldighed forhandles, og hvordan børn imødekommes i kommunerne på tværs af Danmark. I Middelfart kommune kan forældre forvente, at deres barn indgår i en global måltidskultur, hvor alle børn er lige, hvorimod forældre til børn i Glostrup eller Gladsaxe, der ikke spiser svinekød, må forvente, at deres børn får protein-fridage, når der er svinekød på menuen.

\section{Undersøgelsens begraensninger}

Kortlægningen tilbyder en indsigt i, hvordan kommunerne retningssætter mangfoldighed i måltidet på policy niveau. Det beskriver altså politikkernes forskellige forventninger til, hvordan mangfoldighed håndteres omkring måltidspraksisser. I en diskursanalytisk præmis reflekterer kostpolitikkerne de kommunale ideologiske visioner, samtidig med at kostpolitikken former måltidspraksisser. Meningen i retningslinjerne er på en og samme tid formet af ordvalget og afspejler kommunalpolitikernes forståelse af den kontekst børn, forældre og pædagogisk personale indgår i (Laclau \& Mouffe, 1985). De metodologiske begrænsninger må derfor også anerkendes. En diskursanalytisk tilgang til kostpolitikkernes skrevne ord kan sige noget om de bagvedliggende ideologiske værdisæt og strukturerende kræfter, der former den sociale kontekst, som politikkerne er opstået i. Fundene kan 
dog ikke forstås som absolutte, da de kan tolkes forskelligt. Endvidere eksisterer diskurserne kun inden for et diskursanalytisk perspektiv på politikkerne. Studiet kan derfor ikke afdække den faktiske hverdag, børnene møder. Praksis kan være mere nuanceret og rig, end et politisk dokument kan indfange. Om end det må forventes, at kommunernes officielle retningslinjer udgør et retningsgivende arbejdsredskab, som praktikerne forventes at omsætte i praksis. En anden begrænsning, som må anerkendes, er politikkernes tekstmæssige karakter og omfang. Nogle politikker har et overordnet udtryk og optræder i punktform med kortfattet tekst, og andre poltikker optræder med længere tekstpassager. Det kortfattede udtryk kan være en begrænsning for forståelsen af kommunernes forståelse af mangfoldighed og den måltidspædagogiske opgave, da det er kommunens ordvalg som gøres til genstandsfelt i en diskursanalyse, som dette studie er. Det er også problematisk for praktikerne i kommunens dagtilbud, som skal fortolke kommunens retningslinjer og omsætte disse i praksis.

\section{Konklusion}

Studiets formål var at kortlægge, hvordan danske kommuner forhandler mangfoldighed i kostpolitikker for dagtilbud. På trods af studiets ovennævnte begrænsninger, er undersøgelsens fund vigtige for debatten om dagtilbuddets måltidspædagogiske opgave. Studiet viser, at der på kommunalt policy niveau er store forskelle på kommunernes forhandling af mangfoldighed, hvor over halvdelen $(55 \%)$ af danske kommuner ikke har en entydig politisk retning, der garanterer, hvordan mangfoldighed håndteres i dagtilbuddene. Kortlægningen består af et kontinuum med ni mellempositioner mellem en nationalkonservativ og kosmopolitisk yderpol. Dette skyldes store forskelle på forhandlingen af mangfoldighed og den måltidspædagogiske opgave i kommunernes kostpolitikker, som eksplicit forholder sig til mangfoldighed.

Kortlægningen viser, at mad og måltider bidrager til at skabe et fællesskab, men at dette fællesskab kan have forskellig karakter i forhold til børns deltagelsesmuligheder i den fælles forhandling af mening. I den nationalkonservative ende af kontinuumet bidrager maden til at skabe en særlig fortælling om dansk madtradition. Dette sker gennem en italesættelse af, at sund mad er lig med dansk mad. Dertil samler dansk mad ét Danmark i en homogen gruppe defineret af mennesker, som spiser svinekød, hvilket bidrager til at skabe et særligt fællesskab omkring måltidet baseret på en distinktion mellem os og dem, hvor børn udpeges som illegitime på baggrund af deres fravalg af svinekød. Maden fungerer på den måde som et normaliserende redskab over for børn, der står uden for den homogene gruppe af danskere.

I den anden ende af kontinuummet afspejler maden og måltidet den aktuelle børnegruppes sammensætning og bidrager til at skabe et fællesskab med globalt udsyn og anerkendelse af, at smagog madpræferencer er individuelle. I mellem disse yderpoler optræder ni mellempositioner med forskellige forhandlinger af den måltidspædagogiske opgave og balancen mellem dansk madtradition, der inkluderer svinekød, og hensyn til børn, der fravælger at spise svinekød. Fælles for de kommunale kostpolitikker er, at måltidet kan forstås som et socialt mødested, hvor kommunens børn, praktikere, forældre og kommunalpolitikere deltager i og om et socialt, kulturelt og politisk projekt, men der ikke konsenssus om forståelsen og håndtering af dette projekt og dagtilbuddets måltidspædagogiske opgave. 


\section{Referencer}

Andersen, J., Gundelach, S. \& Rasmussen, K. (2004). Kommunernes kostordninger og kostpolitikker i daginstitutioner. En landsdakkende undersøgelse. Århus: UdviklingsForum I/S.

Bae, B. (2009). Samspill mellom barn og voksne ved måltidet. Muligheter for medlæring? Tidsskrift for Nordisk Barnehageforskning, 2(1). https://doi.org/10.7577/nbf.246

Beardsworth, A., \& Keil, T. (1997). Sociology on the menu : an invitation to the study of food and society. London: Routledge.

Birnbaum, P. (2013). La République et le Cochon. Paris: Seuil.

Bourdieu, P. (1979): La Distinction: critique sociale du jugement. Paris: Éditions de Minuit, cop.1979.

Børne- og Socialministeriet (2015). Dagtilbudsloven.

COWI (2007). Undersøgelse af mad- og bevagelsespolitikker i kommunerne - Status, udfordringer og behov $i$ skoler og dagtilbud. Fødevarestyrelsen

Dahlberg, G., Moss, P. \& Pence, A. (2013). Beyond quality in early childhood education and care: languages of evaluation (Classic edition 3. ed. ed.). Abingdon: Routledge.

DeSoucey, M. (2010). Gastronationalism: Food Traditions and Authenticity Politics in the European Union. American Sociological Review, 75(3), 432-455. https://doi.org/10.1177/0003122410372226

Danmarks Radio (2018). Partier: Svinekød i vuggestue er politisk beslutning. 10. feb. 2018. Retrieved from https://www.dr.dk/nyheder/politik/partier-svinekod-i-vuggestue-er-politisk-beslutning

Fischler, C. (1980). Food habits, social change and the nature/culture dilemma. Social Science Information, 19(6), 937-953. https://doi.org/10.1177/053901848001900603

Halkier, B. (2012). Mad, sundhed og minoritetsfamilier. In L. Holm \& S. T. Kristensen (Eds.), Mad, mennesker og måltider - samfundsvidenskabelige perspektiver (Vol. 2. ). København: Munksgaard.

Hart, R. A. (2008). Stepping Back from 'The Ladder': Reflections on a Model of Participatory Work with Children. In A. Reid, B. Bruun Jensen, J. Nikel, \& V. Simovska (Eds.), Participation and learning: Perspectives on Education and the Enviroment, Health and Sustainability: Springer. https://doi.org/10.1007/978-1-4020-6416-6_2

Haukrogh, M. \& Køngerskov, H. (2009). Det falles frokostmåltid : anbefalinger og inspiration til sund mad til børn i daginstitutionen. Søborg: Fødevarestyrelsen.

Holm, L. (2003). Blaming the consumer: On the free choice of consumers and the decline in food quality in Denmark. Critical Public Health, 13(2), 139-154. https://doi.org/10.1080/0958159031000097661

Hunter, I. (2016). Denmark in 'meatball war' as town votes for ALL public buildings to serve pork in backlash against Muslim-friendly menus. MAILONLINE. 20. januar 2016.

Iversen, J. D. (2013). Fødevarestyrelsens kommuneindsatser - en kvalitativ evaluering i forhold til mad og måltider på daginstitutionsområdet. DTU Fødevareinstituttet

Iversen, J. D. \& Sabinsky, M. (2011). En undersøgelse af mad- og måltidskulturen i daginstitutioner med forskellige madordninger. Søborg: DTU Fødevareinstituttet

Jensen, K. O. D. (2012a). Hvad er "rigtig" mad? In L. Holm \& S. T. Kristensen (Eds.), Mad, mennesker og måltider - samfundsvidenskabelige perspektiver (Vol. 2.). København: Munksgaard.

Jensen, K. O. D. (2012b). Mad og identitet. In L. Holm \& S. T. Kristensen (Eds.), Mad, mennesker og måltider - samfundsvidenskabelige perspektiver (Vol. 2.). København: Munksgaard.

Karrebæk, M. S. (2012). “What's in Your Lunch Box Today?”: Health, Respectability, and Ethnicity in the Primary Classroom. Journal of Linguistic Anthropology, 22(1), 1-22. https://doi.org/10.1111/j.1548-1395.2012.01129.x 
Karrebæk, M. S. (2013). Lasagna for Breakfast : The Respectable Child and Cultural Norms of Eating Practices in a Danish Kindergarten Classroom. Food, Culture \& Society, 16(1), 85-106. https://doi.org/10.2752/175174413X13500468045443

Kristansen, E. \& Andersen, K. K. (2015). Et falles måltid - Fordi dit barn fortjener det! Maddag 2015. FOA \& Kost og Ernæringsforbundet

Kristensen, S. T. \& Rasmussen, U. H. (2012). Når mad er gud - moderne sundhedsdyrkelse. In L. Holm \& S. T. Kristensen (Eds.), Mad, mennesker og måltider samfundsvidenskabelige perspektiver (Vol. 2. ). København: Munksgaard.

Laclau, E. \& Mouffe, C. (1985). Hegemony and socialist strategy: towards a radical democratic politics (2nd ed ed.). London: Verso.

Leer, Jonatan (2018/In print). Monocultural and Multicultural gastronationalism: European Journal of Cultural Studies.

Lissau, I., Hesse, U., Juhl, M. \& Davidsen, M. (2006). Mad og fysisk aktivitet i børnehaver, skoler og fritidshjem/skolefritidsordninger: Udviklingen i mad og måltider i skoler og fritidshjem/skolefritidsordninger fra 1999-2004: Statens Institut for Folkesundhed.

Malaguzzi, L. (1993). History, ideas and basic philosophy. In C. Edwards, L. Gandini, \& G. Forman (Eds.), The Hundred Languages of Children: Norwood, NJ: Ablex.

Meyer, C., Mithril, C. \& Blauert, E. (2010). Grundlag for Ny Nordisk Hverdagsmad (The Foundation for and Definition of a New Nordic Diet). Copenhagen: Københavns Universitet, Institut for Human Ernæring.

Mithril, C., Dragsted, L. O., Meyer, C., Blauert, E., Holt, M. K. \& Astrup, A. (2012). Guidelines for the New Nordic Diet. Public Health Nutrition, 15(10), 1941-1947.

https://doi.org/10.1017/S136898001100351X

Møller Christensen, L. \& Hjorth Frandsen, M. (2010). Statusunders $\emptyset$ gelse om kommuners arbejde med mad og måltider i daginstitutioner og skoler 2009. DTU Fødevareinstituttet Afdeling for Ernæring

Nordic Council of Ministers (2004). Nordic Nutrition Recommendations 2004.Copenhagen:

OECD (2017). Key OECD Indicators on Early Childhood Education and Care. Paris: OECD Publishing.

Ritzer, G. (2012). The McDonaldization of society (20. anniversary ed., 7. ed. ed.). Thousand Oaks, Calif.: SAGE.

Smidt, S. (2012). Måltider i daginstitutioner for børn. In L. Holm \& S. T. Kristensen (Eds.), Mad, mennesker og måltider - samfundsvidenskabelige perspektiver (Vol. 2.). København: Munksgaard.

Stamer, N. B. (2016). The Social Dynamics of Food Consumption - Exploring the Role of Values, Taste and Social Class. Copenhagen: University of Copenhagen.

Udenrigsministeriet (1992). FN konventionen om Barnets rettigheder. https://www.retsinformation.dk/Forms/R0710.aspx?id=60837

United Nations (2015). Transforming our world: the 2030 Agenda for Sustainable Development Retrieved from https://sustainabledevelopment.un.org/sdgs

Vands $\varnothing$, A. (2016). Det Danmark, vi spiser [The Denmark, we eat]. Passage, 2(76), 93-71.

Wright, W. \& Annes, A. (2013). Halal on the menu?: Contested food politics and French identity in fast-food. Journal of Rural Studies, 32(2013), 388-399.

https://doi.org/10.1016/j.jrurstud.2013.08.001 


\section{Tabel 1. Analyserede documenter}

\begin{tabular}{|c|c|}
\hline Kommune & Udgivelse \\
\hline Aabenraa & "Børn og Skoles lokale Kostpolitik - for børn og unge i dagtilbud, skoler og døgninstitutioner" (2010) \\
\hline Albertslund & "Mad- og måltidspolitik for dagtilbud, SFO, klub og skoler I Albertslund kommune" (årstal ikke angivet) \\
\hline Allerød & "Kostpolitik og anbefalinger for 0-6 årige børn i daginstitutioner og dagpleje" (2007) \\
\hline Assens & "Madpolitik for børn 0-6 år i dagtilbud i Assens Kommune" (årstal ikke angivet) \\
\hline Billund & $\begin{array}{l}\text { "Overordnet politik for: Mad, Måltider og Bevægelse - en indsats for sundere børn og unge i Billund } \\
\text { kommune" (2011) }\end{array}$ \\
\hline Bornholms & "Appetitvækkeren mad- og måltidspolitik 2015-2017 - Sund mad til børn på Bornholm" (2014) \\
\hline Brøndby & "Mad og Måltidspolitik for børn og unge i dagpleje, daginstitutioner, skoler og SFO'er" (2003) \\
\hline Brønderslev & $\begin{array}{l}\text { "Kost- og bevægelsespolitik for børn og unge i dagtilbud, skoler, skolefritidsordninger og ungdomsskole" } \\
\text { (2010) }\end{array}$ \\
\hline Egedal & "Fakta om frokostordningen 2015-2016" (2015) \\
\hline Esbjerg & "Kostpolitik for Esbjerg kommune" (2010) \\
\hline Faxe & "Politik for Mad, Måltider og Bevægelse" (2009) \\
\hline Fredensborg & "Fredensborg kommunes kostpolitik" (2010) \\
\hline Fredericia & "Strategi for Mad, Måltider og bevægelse 0-18år" (årstal ikke angivet) \\
\hline Frederikssund & "Mad der styrker barnets udvikling" (årstal ikke angivet) \\
\hline Furesø & "Mad- og måltidspolitik for dagtilbud i Furesø Kommune" (2010) \\
\hline Gentofte & "Overordnet mad og måltidspolitik for Gentofte kommune" (2009) \\
\hline Gladsaxe & "Mad og måltider i dagtilbud i Gladsaxe Kommune" (2013) \\
\hline Glostrup & "Mad- og måltidspolitik For 0-6 årige i dagtilbud" (2015) \\
\hline Greve & "Kostpolitik for dagtilbud i Greve Kommune" (2009) \\
\hline Gribskov & "Kost- og bevægelsespolitik For børn og unge i Gribskov kommune" (2009) \\
\hline Guldborgssund & "Kost- og måltidspolitik for dagtilbud i Guldborgssund kommune" (årstal ikke angivet) \\
\hline Haderslev & "Mad- og måltidspolitik for børn og unge i dagtilbud og skoler" (2009) \\
\hline Halsnæs & "Mad- og måltidspolitik for børn og unge i Halsnæs kommune" (2009) \\
\hline Helsingør & "Politik for mad og måltider i dagtilbud - børn 0 - 5 år" (2013) \\
\hline Holstebro & $\begin{array}{l}\text { "Sunde kostvaner 0-6 år - Fællesgrundlag for kost til børn i dagpleje, institution og skole i Holstebro } \\
\text { Kommune" (2015) }\end{array}$ \\
\hline Horsens & "Mad- og måltidspolitik for 0-6 årige - i dagpleje, vuggestue og børnehave" (2011) \\
\hline Hvidovre & "Spisetid - vision for mad og måltider i Hvidovre Kommune" (årstal ikke angivet) \\
\hline Høje-Taastrup & "Mad- og måltidsprincipper for dagtilbud i Høje-Taastrup Kommune" (2011) \\
\hline Hørsholm & "Mad- \& Måltidspolitik For 0-18 års området i Hørsholm Kommune" (årstal ikke angivet) \\
\hline Ishøj & "Ernæringsprincipper for børn og unge 0-16 år" (2009) \\
\hline Jammerbugt & "Politik for madglæde, madmod og fysisk aktivitet for 0-6 årige i dagtilbud" (2015) \\
\hline Kolding & "Sundhed og trivsel for alle" (2011) \\
\hline Lejre & "Kostpolitik i Lejre Kommune" (årstal ikke angivet) \\
\hline Lemvig & "Kostpolitik for 0-2 årige børn i Lemvig Kommunes dagtilbud" (2015) \\
\hline Lolland & "Kost- og bevægelsespolitik for børn og unge 0-16 år i Lolland Kommune" (2008) \\
\hline Lyngby-Taarbæk & "Mad- og måltidspolitik for børn og unge i Lyngby- Taarbæk Kommune" (årstal ikke angivet) \\
\hline Læsø & "Kostpolitik for børn og unge" (årstal ikke angivet) \\
\hline Mariagerfjord & "Mariagerfjord Kommunes Mad- og måltidspolitik" (årstal ikke angivet) \\
\hline Middelfart & $\begin{array}{l}\text { "Overordnet kostpolitik - Gældende for børn og unge i dagtilbud, skoler og klubber i Middelfart Kommune" } \\
\text { (årstal ikke angivet) }\end{array}$ \\
\hline
\end{tabular}




\begin{tabular}{|c|c|}
\hline Morsø & $\begin{array}{l}\text { "Morsø Kommunes overordnede sundhedsfaglige Mad- og måltidspolitik Til: Dagplejen, Daginstitutioner, } \\
\text { Puljeordninger, Skoler, Skoleboder, Fritidsordninger" (2003) }\end{array}$ \\
\hline Nyborg & "Overordnede retningslinjer for førskoleområdet" (2015) \\
\hline Næstved & "Mad, Måltider Bevægelse til og med for børn og unge"(2012) \\
\hline Odder & "Mad- og Måltidspolitik - for børn og unge i kommunale skoler, daginstitutioner og dagpleje" (2008) \\
\hline Rebild & "Mad- og måltidspolitik i Rebild Kommune" (2010) \\
\hline Roskilde & "Nyt Fokus på Sund Mad - Roskilde Kommunes kostpolitik" (2008) \\
\hline Rudersdal & "Mad- og Måltidspolitik" (årstal ikke angivet) \\
\hline Rødovre & "Overordnede retningslinjer for kost for børn og unge i alderen 0-18 år"(2009) \\
\hline Skanderborg & "Kostpolitik - daginstitutionsområdet" (årstal ikke angivet) \\
\hline Slagelse & "Kostpolitik for skole og daginstitutioner i Slagelse Kommune" (2013) \\
\hline Solrød & "Kostpolitik i Dagtilbud for 0-6 årige i Solrød Kommune" (årstal ikke angivet) \\
\hline Stevns & "Kostpolitik i daginstitutioner" (2007) \\
\hline Struer & "Overordnet Kostpolitik - det gode måltid" (2001) \\
\hline Svendborg & $\begin{array}{l}\text { "Mad- og måltidspolitik - for børn og unge 0-16 år i Svendborg Kommunes dagtilbud, skoler og SFO'er" } \\
\text { (årstal ikke angivet) }\end{array}$ \\
\hline Syddjurs & $\begin{array}{l}\text { "Mad - og bevægelsespolitik i Syddjurs kommune for børn og unge i skoler, dagtilbud og juniorklubber" } \\
\text { (2008) }\end{array}$ \\
\hline Thisted & "Kostpolitik" (2009) \\
\hline Tønder & "Måltidspolitik på dagtilbudsområdet" (2015) \\
\hline Vallensbæk & "Vallensbæk Kommunes Kostpolitik - for 0 til 6 årige børn i daginstitutioner og dagpleje" (2013) \\
\hline Vejle & "Inspirationshæfte til institutionernes mad- og måltidspolitik - for 0-6 årige i Vejle Kommune" (2007) \\
\hline Vesthimmerlands & "Kostpolitik 0-6 år" (2009) \\
\hline Viborg & "Kostpolitik" (årstal ikke angivet) \\
\hline Vordingborg & "Vejledning om sundhed og sikkerhed i dagtilbud" (2013 - redigeret 2015) \\
\hline Arø & "Kostpolitik" (2009) \\
\hline Århus & "Århus Kommunes Kostpolitik - for børn i kommunale dagtilbud" (2004) \\
\hline
\end{tabular}

